\title{
INTEREST RATE CHANNEL OF MONETARY POLICY TRANSMISSION MECHANISM AND COMMERCIAL BANKS EARNINGS IN NIGERIA
}

\author{
Dr. K. C. Uzah¹, Amini Maton-Awaji Clinton² and Leera Kpagih² \\ ${ }^{1}$ Department of Banking and Finance, Rivers State University, Nkpolu - Port Harcourt, \\ Rivers State, Nigeria \\ ${ }^{2}$ Department of Economics, Rivers State University, Nkpolu - Port Harcourt, Rivers State, \\ Nigeria
}

Cite this article:

Uzah K. C., Clinton A.M., Kpagih L. (2021), Interest Rate Channel of Monetary Policy Transmission Mechanism and Commercial Banks Earnings in Nigeria. African Journal of Accounting and Financial Research 4(3), 194-214. DOI:

10.52589/AJAFRHGH92RHA.

\section{Manuscript History}

Received: 13 Nov 2021

Accepted: 5 Dec 2021

Published: 27 Dec 2021

Copyright $\odot 2020$ The Author(s). This is an Open Access article distributed under the terms of Creative Commons AttributionNonCommercial-NoDerivatives 4.0 International (CC BY-NC-ND 4.0 ), which permits anyone to share, use, reproduce and redistribute in any medium, provided the original author and source are credited.
ABSTRACT: This study examined the interest rates channel of the monetary policy transmission mechanism and the earnings of commercial banks in Nigeria. The objective was to investigate the extent to which the interest rates channel of the monetary policy transmission mechanism affects the earnings capacity of the quoted commercial banks. Time series data were sourced from annual financial reports of the commercial banks and the Central Bank of Nigeria statistical bulletin's various issues. Earnings measures such as earnings per share and earnings before interest and tax were modeled as the function of Monetary Policy Rate, Prime Lending Rate, Short-term Savings Rate, Long-term Saving Rate and Maximum Lending Rate. The Ordinary Least Square method of Regression Analysis was used to estimate the relationship between the dependent and the independent variables. Augmented Dickey Fuller Test, Johansen Cointegration Test, Granger Causality Test and Vector Error Correction Test were used to determine the dynamic relationship among the variables. Findings showed that short-term and longterm savings rates have negative effects while monetary policy rate, maximum lending rate and prime lending rate have positive effects on the earnings capacity of Nigerian commercial banks. Therefore, we recommend that interest rate policies should be integrated with the earning objectives of the commercial banks.

KEYWORDS: Interest Rates Channel, Monetary Policy Transmission Mechanism, Commercial Banks’ Earnings. 


\section{INTRODUCTION}

The conventional role of banks has been that of intermediary bringing together of borrowers and lenders, which can only be done successfully and sustainably with careful management of credit, liquidity and interest rate risk (Rand, 2009). Monetary policy has an effect on how banks conduct their businesses. It is therefore imperative to understand how banks respond to the policy stance adjusting their traditional role and duty to ensure efficient financial resource allocation in the economy. How banks respond depends on the structure of the market and the specific bank size, among other factors.

Monetary policy is one of the key policies within an economy upon which the growth, development and sustainability of economic activities rest upon. The processes are referred to as monetary policy transmission mechanism channels and come in different forms. Under the traditional channel, the assumption is that financial intermediaries such as banks offer no special services on the asset side of their balance sheets. However, this channel is incomplete in the sense that it offers no analysis of distribution or cross-sectional responses to policy actions. This deficiency is nonetheless met by credit view reasoning through establishing the role played by banks. Historically, interest rate was first used as the instrument of monetary policy in 1962 following the introduction of money market instruments (Eregha, 2010). However, in the past decades, specifically after the deregulation of the financial market, the monetary authorities through the monetary policy channel have formulated various interest policies, such as the deregulation of interest rate in the last quarter of 1986.

While the interest rate channel operates through the demand for loans, it is important to investigate whether there are relevant supply-side effects in the credit market that further affect monetary policy transmission. The central bank must understand the extent to which individual bank's characteristics and the nature of the banking sector can amplify or cushion its efforts so as not to destabilize the economy. Identifying the transmission channels is important because they determine the most effective set of policy instruments, the timing of policy changes, and hence, the main restrictions that central banks face in making their decisions (Loayza \& Schmidt-Hebbel, 2002). The traditional interest view has failed to explain empirically how monetary policy affects the economy, a gap closed by the credit channel in the light of asymmetric information. Bernanke and Gertler (1995) further argued that the relatively large fluctuations in aggregate spending, such as business fixed investment and inventory investment, cannot be fully explained by minor changes in the real interest rates. The regulatory framework has a bearing on the nature of the market thereof and hence, the behaviour of individual or group of banks faced with a monetary policy shock.

Empirical literature assigns an inimitable role to banks in the monetary policy transmission, the interest rate channel most conventional mechanism and the one used in empirical studies to embody the joint effect of all the channels. It is the mechanism that underlies public intuition and media debates on the role played by monetary policy in modern economies. It combines the central bank's ability to affect a real interest rate and the existence of intertemporal substitution elasticity on the components of aggregate demand.

Variations of the amount of money changes through the nominal interest rate have a direct effect on the level of commercial activities. The shift in the real interest rate impacts consumption, investment and the output level and prices. The effectiveness of monetary policy will depend not only on its ability to affect the real interest rate, but also on the sensitivity of 
consumption and investment to changes in the price of intertemporal substitution. The elasticity of aggregate demand to the interest rate (both absolute and relative) will determine how, when, and to what extent the monetary policy will affect the economy. Furthermore, the increase in the interest rate might not only have a substitution effect that discourages investment and consumption, but could also create wealth effects depending on the borrowing or lending position of economic agents. Factors that determine commercial banks earnings have well been documented in literature; however, there are limited studies of citable significance that examine the interest channel of monetary policy transmission mechanism and commercial banks earnings in Nigeria. We filled this knowledge by modeling commercial banks earnings as the function of the interest rate channel of the monetary policy transmission mechanism.

\section{LITERATURE REVIEW}

\section{Interest Rate Transmission Mechanisms}

This is the most conventional mechanism and, at the same time, the one used in empirical studies to embody the joint effect of all the channels. It is the mechanism that underlies public intuition and media debates on the role played by monetary policy in modern economies. It combines the central bank's ability to affect a real variable (the interest rate) and the existence of intertemporal substitution elasticity on the components of aggregate demand.

The central bank induces the variations of the amount of money changes through the nominal interest rate. The shift in the real interest rate impacts consumption and investment (including inventory) and the output level and prices. The effectiveness of monetary policy depends not only on its ability to affect the real interest rate but also on the sensitivity of consumption and investment to changes in the price of intertemporal substitution. The elasticity of aggregate demand to the interest rate, both absolute and relative, will determine how, when, and to what extent the monetary policy will affect the economy. Furthermore, the increase in the interest rate might not only have a substitution effect that discourages investment and consumption, but could also create wealth effects depending on the borrowing or lending position of economic agents.

In an underdeveloped financial market, the monetary authority control (direct or indirect) on the interest rates of other instruments can be large, thereby aiding the transmission of the policy decisions. The market can also interpret current interest rate movements as a signal of future monetary policy actions, making longer term rates react consistently. A decline in interest rates, for example, can be construed as a factor that will raise future inflation. Since a contractionary monetary policy is expected to offset such an increase in inflation, long term rates may end up increasing as a reflection of the expected increase in the future policy rate and the basic model does not consider financial intermediation. It describes an economy with no banks, where borrowers and lenders exchange their resources directly. Therefore, a rise in the interest rate caused by a monetary contraction will result in discarding only those investment or consumption projects whose expected return, adjusting by risk, is lower than its financing cost. In this sense, no inefficiencies exist in the way of investment or consumption contracts, as opposed to the credit mechanism (Cecchetti, 1999). Resources are assigned efficiently at the given interest rate. 
Another dimension, which is relevant for all transmission mechanisms described herein, is the source of the market imperfection that generates the real effect of the nominal policy change. Be it some price/wage rigidity in the neo Keynesian tradition or an information problem as suggested by a Lucas-type supply function, one can expect that if agents are rational, the real effect of a monetary shock is smaller (or non-existent) in unstable economies. The short-run Phillips curve can become vertical in a context of macroeconomic instability. For instance, economies in which inflation is more volatile should be associated ceteris paribus to smaller output effects of a given monetary shock (Cameron \& Safaei, 2003).

\section{Investment-Based Channels: Direct Interest-Rate Channels}

According to classical economists, the traditional channels of monetary transmission that have been embedded in macroeconomic models involve the impact of interest rates on the cost of capital and hence on business and household investment spending (residential and consumer durables investment). Standard neoclassical models of investment demonstrate that the user cost of capital is a key determinant of the demand for capital, whether it is investment goods, residential housing or consumer durables. The user cost of capital (uc) can be written as:

$u_{c}=p_{c}\left[(1-\tau) i-\pi_{c}^{e}+\delta\right]$

where $p_{c}$ is the relative price of new capital, $i$ is the nominal interest rate, $\pi_{c}^{e}$ is the expected rate of price appreciation of the capital asset, and $\delta$ is the depreciation rate. The user cost formula also allows for the deductibility of the interest rate by adjusting the nominal interest rate by the marginal tax rate $\tau$. Regrouping terms, the user cost of capital can be rewritten in terms of after-tax real interest rate, $(1-\tau) i-\pi^{e}$, and the expected real rate of appreciation of the capital asset, $\pi_{c}^{e}-\pi^{e}$, where $\pi^{e}$ is the expected inflation rate such that

$\left.u_{c}=p_{c}\left\{(1-\tau) i-\pi^{e}\right\}-\left\{\pi_{c}^{e}-\pi^{e}\right\}+\delta\right]$

Several factors are important in determining the effects of monetary policy operating through these direct user-cost channels. The first regards the horizon over which interest rates influence spending. Because capital assets are long-lived and the adjustment of these stocks involves costs (of planning, procurement, installation, etc.), businesses and households take the long view when factoring variation in interest rates into their investment decisions. As a result, the real interest rate and the expected real appreciation of the capital asset that influences spending will typically be related to the expected life of the asset, which is often very long.

With the monetary policy instrument being a short-term interest rate, this discussion makes clear that the monetary transmission mechanism involves the link between short and long-term interest rates through some version of the expectations hypothesis of the term structure. When monetary policy raises short-term interest rates, long-term interest rates also tend to rise because they are linked to future short-term rates. Consequently, the user cost of capital rises and the demand for the capital asset falls. The decline in the demand for the capital asset leads to lower spending on investment in these assets and so causes aggregate spending and demand to decline. 
The investment decisions of firms and households can also be considered in the framework of James Tobin (1969). For business investment, Tobin (1969) defined $q$ as the market value of firms divided by the replacement cost of capital. When $q$ is high, the market price of firms is high relative to the replacement cost of capital and new plant, and equipment capital is cheap relative to the market value of firms. Companies can then issue stock and get a high price for it relative to the cost of the facilities and equipment they are buying. As a result, investment spending will rise because firms can buy a lot of new investment goods with only a small issue of stock. In principle, similar reasoning could be applied to household investment decisions.

Tobin's $q$ theory can be linked to the user cost of capital approach, as shown by, for example, Hayashi (1982). Indeed, the q-formulation dominates formal micro-based modeling efforts and in large part because the formal links between q-theory and the user-cost approach in the dynamic adjustment cost approach of Hayashi (1982) allow for convenient analytical expressions in such models. In addition, the $\mathrm{q}$ approach does add a degree of richness, as it emphasizes that there is a direct link between stock prices and investment spending. In practice, Tobin's $q$ therefore leads to another channel of monetary transmission: When monetary policy is eased and interest rates lowered, the demand for stocks increases and stock prices rise, thereby leading to increased investment spending and aggregate demand.

\section{Consumption-Based Channels: Wealth Effects}

Standard applications of the life-cycle hypothesis of saving and consumption, first developed by Brumberg and Modigliani (1954) and later augmented by Ando and Modigliani (1963), indicate that consumption spending is determined by the lifetime resources of consumers, which includes wealth, whether from stock, real estate or other assets. Expansionary monetary policy in the form of lower short-term interest rates will stimulate the demand for assets such as common stocks and housing, thereby driving up their prices; alternatively (and equivalently), lower interest rates lower the discount rate applied to the income and service flows associated with stocks, homes, and other assets, driving up their price. The resulting increase in total wealth will then stimulate household consumption and aggregate demand. Standard lifecycle wealth effects operating through asset prices are thus an important element in the monetary transmission mechanism.

\section{Intertemporal Substitution Effects}

A second consumption-based channel reflects intertemporal substitution effects. Indeed, this channel is central to the models. In this channel, changes in short-term interest rates alter the slope of the consumption profile, so that lower interest rates induce higher consumption today. This channel naturally arises through the models' use of the standard consumption Euler equation, linking the marginal rate of substitution between current and future consumption with the real interest rate.

\section{The Monetarist and Transmission of Monetary Policy}

- The traditional textbook (Keynesian) channel is known as the interest rate or the intertemporal substitution channel:

$(M \uparrow \Rightarrow) i \downarrow \Rightarrow C \uparrow(1 \uparrow) \Rightarrow Y^{d} \uparrow \Rightarrow y \uparrow \Rightarrow \Pi \uparrow$ 
- Expanding 'money' $(\mathrm{M})$ reduces interest rates (i), reduces the cost of borrowing for firms (and consumers), leads to increased consumption (C) as well as investment (I) and therefore higher demand $\left(\mathrm{Y}^{\mathrm{d}}\right)$, a bigger output gap (y) and finally higher prices and inflation $(\pi)$.

\section{The Interest Rate Channel and Policy Responses}

- Bernanke and Gertler (1989) stated that the macroeconomic response to policy-induced interest rate changes was considerably larger than implied by conventional estimates of interest elasticity of consumption and investment.

This suggests that mechanisms other than the interest rate channel may also be at work in the transmission of monetary policy.

\section{THEORETICAL FRAMEWORK}

\section{Pure Expectations Theory of Interest Rate}

This theory states that long-term rates reflect the expectations of future short-term interest rates, which implies that the return on long-term bonds is the same as the expected return on a series of short-term bonds during the same period. In this case, the market should be efficient in the sense that no time arbitrage is available, and therefore the bond pricing becomes an easy task. This theory is the most popular and the most empirically tested. However, not all authors support this theory using data. The theory is however simple and can be used for constructing more complicated models. This may be the reason why it is tested over and over again. The result is that the Pure Expectations hypothesis almost never holds for short-run changes of long-term rates, but it is pretty often true for changes in short-term rates for long-run changes (Campbell \& Shiller, 1991). The theory, sometimes, is also the only one to be used for emerging capital markets due to undeveloped financial instruments and absence of strict market segments (Drobyshevsky, 1999).

\section{Liquidity Premium Theory}

This was developed by Hicks (1946). It allows the long-term interest rate to deviate from the expected short-term rate. In this case, the additional assumption on investors' preferences is made. The return on short-term bonds is assumed to be more or less certain while the return on long-term bonds is not. In the long run, some shocks can appear but long-term bonds are not liquid enough to react to shocks immediately and this would lower the actual gain from holding the bond. Therefore, investors would like to get additional interest called the liquidity premium for this uncertainty and long-term interest rates deviate are higher than expected short-term ones.

\section{The Market Segmentation Theory}

This was introduced by Culbertson (1959). It assumes that investors have strict maturity preferences. In this case, pension funds with long-term liabilities would invest in similar bonds while banks would operate on a shorter horizon. This implies the existence of separated market segments each having an interest rate determined by its own supply-demand interaction. The 
yield curves under this hypothesis are not even expected to be continuous over different maturity periods.

\section{The Loanable Funds Theory}

This is a flow theory that determines the interest rate by the interaction of demand for and supply of loanable funds or credit (Ngerebo-a, 2012). It involves the linking of the interest rate with non-savings, investment and hoarding of funds sourced from government, businessmen and consumers, on the demand side with savings, dishoarding and bank money on the supply side from private individuals and corporate bodies.

\section{Keynesian Liquidity Preference Theory}

Keynesian liquidity preference theory is a stock theory. The theory determines the interest rate by the demand for and supply of money. It emphasizes that the rate of interest is a purely monetary phenomenon as distinct from the real theory of the classics. It is a stock analysis because it takes the supply of money as given during the short run and determines the interest rate by liquidity preference or demand for money.

\section{Monetary Policy and Interest Rate}

Both the classical and the Keynesian theories of interest rate are built on the policy variables. Several empirical findings effectively support the opinion that long-term nominal interest rates are affected by monetary policy through its impact on inflation. Campbell and Ammer (1993) found that returns from bonds are largely driven by news about future inflation, while real rates have little impact. They also found small differences in the variance decomposition of bond returns according to the sample period. While the variation in bond returns is essentially explained by news about future inflation over the 1952-1979 periods, the news about future excess bond returns also contributes to the overall variance of bond returns in sample periods that include the 1980s. Mehra (1996) used cointegration and error-correction methodology in a multivariate framework and found a long run equilibrium relationship that exists between the US bond rate and the inflation rate, that can be interpreted as a Fisher relation in which the rate of inflation determines the bond rate. The long-run effect of monetary policy on bond yields occurs therefore primarily through the inflation channel. Evans and Marshall (2001) used structural VAR models and found that monetary policy shocks have a significant impact on the slope of the yield curve, but no effect on the level of the yield curve. Wu (2003) also used the same approach; the result confirms that monetary policy shocks have a large and significant but short-lived effect on short-term interest rates with a dissipating effect on longer-term interest rates. Roley and Sellon (1995) expected future monetary actions to find a larger response of long-term interest rates to monetary policy than traditionally: they found that the magnitude of the response of long-term interest rates to monetary actions depends on the expected persistence of those actions. 


\section{EMPIRICAL REVIEW}

Boivin et al. (2008) suggested that there was evidence of important changes in the transmission of monetary policy since the start of the European Monetary Union. They also found that the exchange rate channel had become more powerful in the monetary union period than in the previous decade. They used a Factor Augmented Vector Autoregression model proposed by Barnanke.

James and Tamim (2001) suggested that policy measures to strengthen banks were a probable prerequisite to restoring the effectiveness of the monetary transmission mechanism. They used a VAR framework in the evaluation of monetary policy in Japan, with results showing that both banks' balance sheets and monetary are important sources of shocks and that banks play an important role in transmitting monetary shock to economic activities. Karagiannis et al. (2010) suggested that the Money Market (MM) rate compared to the Central Bank (CB) rate is more effective as a policy vehicle variable in the Euro-Zone. They used monthly data from the USA and Euro-zone and found that not all of the change in the policy rate is transmitted to the loan rates. His findings in the USA analysis were that CB rate increases and decreases are both transmitted to the deposit and loan rates, and that MM rate is not transmitted to the retail rates, which probably show that the MM does not work effectively as a policy vehicle variable in the USA. Findings by Opiyo (2010) in the authors study on monetary policy transmission on Economic growth in Kenya suggests that there is a positive contribution of treasury bill rate and required reserve ratio to the cost of credit. Monetary transmission mechanism has a strong influence on credit growth, cost of credit and amount of deposit in Kenya. Further analysis by the author suggests that there is an inverse relationship between real money supply, required reserve ratio and Treasury bill rate. The researcher therefore concludes that an action by CBK to lower the required reserve ratio, Treasury bill rate or both will immensely increase the amount of money supply in the economy. The author used data between 1997 and 2009 and the Structural Vector Autoregressive Model (SVAR).

Cavik and Teksoz (2012) note that one weakness of the SVAR model is that the estimation results are sensitive to the identifying assumptions which can lead to substantial variations in the estimated effects of monetary policy and in their relative importance over the sample period. Munyanzwe (2011) noted that the exchange rate transmission channel is not significant in explaining the variability of the consumer price index when it interacts with financial innovation variables M2/M1 (ratio of broad money to narrow money and bank credit to GDP. The researcher's study sought to examine the effectiveness of exchange rate transmission chances of monetary policy in Kenya amidst rapid financial innovation using the regression analysis. The research observed the impact of exchange rate in explaining CP1 volatility when the exchange rate interacts with financial innovation variables. The author used data from 2001q1-2010. The results are consistent with Misati et al. (2010) who used financial innovation variables represented by Bank to Gdp ratio and M3/M2. They found that increased financial innovation will lead to efficiency in access of finances to households and firms and therefore, more investments which lead to increased output. However, the overall effects suggest that with financial innovation, the effectiveness of interest rate channels in monetary transmission is weakened and so, as financial innovation intensifies, the more positive the output gap is likely to be. 
Results by Mburu (2012) suggest that changes in money supply are the predominant determinants of changes in inflation as the coefficient of change in money supply is highest at $41 \%$, which was consistent with the monetarists theory that the effect of an expansionary monetary policy on an economy operating at optimum level is inflationary in nature. Also, the results suggest that change in interest rate follows closely with changes in exchange rate being the last significant variable with a coefficient rate of $21 \%$. Masati and NyamOngo (2011), in their paper on asset prices and monetary policy in Kenya, shed light on issues on linkages between monetary policy and financial stability. Empirical analysis was based on quantitative analysis which incorporates both descriptive analysis and empirical approach where the study employed use of the VAR approach. Findings were that while monetary policy effects on stock prices volatility do not last for long, instability in the stock market prices creates instability in GDP and inflation, and that the asset price channel of monetary transmission mechanism in Kenya is not compelling.

Maturu (2006) found that contrary to other researchers' evidence that inflation is one of the most dominant determinants of money, it actually is not. Moreover, results suggest that interest rate shock temporarily reduced real output for the first 4 months and permanently reduced money rates on credit and finally, the importance of credit in the explanation of movements in inflation and income. Consistent with the IRF, the variance decomposition suggests that there was weak pass through from interbank rate and $\mathrm{Tb}$ rate to prime lending rate and that there was no strong relationship and pass through effects among the variables, particularly between shortterm interest rates and lending rates. But the positive aspect was that while the relationship may not have been strong, they nevertheless existed. The results also show that the model also suggests high liquidity in financial systems was one of the reasons for incomplete Repo pass through. The results are not consistent with Kendall (2001) whose findings suggest that Trinidad's interest rate response was strongest and most consistent. Cheng (2006) discovered that Kenya's nominal exchange rate is highly susceptible to monetary policy with appreciation following an increase in the short-term interest rates and that monetary policy seemed to have little impact on real output. The author used the vector autoregressive model, using data between 1997 and 2005. His findings suggest that the possible explanation for the sluggish response of output to monetary policy shock is the weak financial system, plagued with structural weaknesses.

Saborowski and Weber (2013), in their study on assessing the determinants of interest rate transmission through conditional impulse response function, they employed the use of a panel VAR framework and supported their choice of the panel VAR on the premise that it uses monthly data instead of annual data to assess how a country affects not only long run pass through but also its dynamics over time. In addition, the model permits computing a country's specific pass through and decomposing these into the respective contributions of the different countries characteristic. Results suggest that structural characteristics that matter for interest rate transmission are exchange rate flexibility, regulatory quality, financial development, dollarization, inflation and finally, banking sector related variables such as competition, ratio of liquidity to assets and as an indicator of asset quality, the performance of bank's loan portfolios. Their findings suggest that an increase in banking sector liquidity from 20th to 80th percentile is associated with a fall in pass through of around 20 percentage points. An increase of between 25 and 50 percentage points was as a result of moving from a pegged to a floating exchange rate regime. 
Contrary to Davoodi et al. (2013), whose results generally suggest that monetary policy measured by shock to policy rate, has long lags to prices and output of all EAC nations. The results are equally shared by Morales and Raei (2013) who suggest there was evidence for the existence of interest rate and exchange rate channels of monetary policy in EAC. Nyamongo and Ndirangu (2010), in their paper on financial innovation and monetary policy in Kenya, noted that financial innovation has positive outcomes and seems to improve the interest rate channel of monetary policy transmission. The study was conducted using data from the period 1998-2012. Tests were carried out on stability of velocity of circulation, money multiplier and money demand with use of impulse response function, with results showing that innovation has improved the monetary policy environment in Kenya. Results from Misati et al. (2010) differ from those of Nyamongo and Ndirangu (2013) studied on financial innovation and monetary policy transmission, applied use of two stage least squares (2SLS), and monthly data covering the period 1996-2007. Based on their findings, they concluded that financial innovation poses complex challenges to the conduct of monetary policy and thus, financial innovation dampens the interest rate channel of monetary transmission mechanism.

Ngerebo-a and Lucky (2016) examined interest rates and the profitability of commercial banks in Nigeria from 1980-2014. The objective was to investigate the extent to which various interest rate measures affect profitability performance of the quoted commercial banks. Time series data were sourced from annual financial reports of the commercial banks and Central Bank of Nigeria (CBN) statistical bulletin's various issues. Profitability measures such as Return on Investment (ROI), Return on Assets (ROA) and Return on Equity (ROE) were modeled as the function of Monetary Policy Rate (MPR), Prime Lending Rate (PLR), Shortterm Savings Rate (STSR), Long-term Saving Rate (LTSR), Treasury Bill Rate (TBR) and Maximum Lending Rate (MLR). The Ordinary Least Square (OLS) method of Regression Analysis was used to estimate the relationship between the dependent and the independent variables. Augmented Dickey Fuller Test (ADF), Johansen Cointegration Test, Granger Causality Test and Vector Error Correction (VEC) Test were used to determine the dynamic relationship among the variables. Findings showed that the independent variables have greater impact on ROI and ROA than ROE. The Granger Causality proved no casual relationship between the variables. Therefore, we recommend that interest rate policies should be integrated with profitability objectives of the commercial banks.

Khan and Sattar (2014) investigated the impact of interest rate on the profitability of four major commercial banks in Pakistan within the period 2008-2012 using pension condition methods. They found that there is a positive and significant relationship between interest rate and profitability. Baghan and Chowdy (2010) found that bank profit is derived from the difference between the interest rate it charges by lending and the interest rate it offers depositors. Ogunbiyi and Peters (2014) examined how interest rates affect the profitability of Deposit Money Banks (DMBs) in Nigeria using country aggregate level annual data that covered 1999 to 2012, with the aid of multivariate regression analysis under an econometric framework. The augmented Dickey and Fuller Unit Root Test results indicate that the series have 1 (0), 1(1) or 1(2) significant effect on profitability of Nigerian DMB as measured by ROA at $5 \%$ level of significance. Real interest rate, at 5\% level of significance, had a negative and significant relationship with ROE. The study found no significant relationship between interest rate variables and net interest of DMB in Nigeria. 
Okoye and Eze (2013) examined the impact of bank lending rate on the performance of Nigerian (DMBs) between 2000 and 2010. It specifically determined the effects of lending rate and monetary policy rate, and analyzed how bank lending rate policy affects the performance of Nigerian DMBs. Findings revealed that lending rate and monetary policy rate have significant and positive effects on the performance of Nigerian DMBs. Enyioko (2012) investigated the performances of twenty (20) out of twenty-five (25) banks in Nigeria based on the interest rate policies of the banks, and found that interest rate policies have not improved the overall performances of banks significantly.

\section{Research Gap}

From literature, different authors have given mixed results, some bearing results that agree while others results that contradict one another. There is limited literature on the long run effects of interest rate channel effects on commercial earnings, most especially the developing countries of Africa and Nigeria to be specific.

\section{Methodology}

Time series data were sourced from financial statements of the commercial banks and the Central Bank of Nigeria Statistical bulletin and annual reports of the commercial banks; the models specified below are based on theory and empirical studies. The method of data analysis used in this study is the multiple linear regressions using ordinary least squares method—using ordinary least squares with Econometric View regression analysis.

\section{RESEARCH METHODOLOGY}

This section contains the methodology employed in analysing the data. It provides the empirical strategy and estimation techniques, analytical framework, model specification, as well as the description and sources of the data. This study uses a quasi experimental research design approach for the data analysis. This approach combines theoretical consideration (a prior criterion) with the empirical observation and extracts maximum information from the available data. It enables us therefore to observe the effects of explanatory variables on the dependent variables. From theories, principles and empirical findings, the model below is specified in this study. To bring the independent variables to equal value to the dependent variables, the variables are deflated using total assets of deposit money banks.

$E P S=f(S R, P L R, M P R, M L R, L S R$,

It is empirically stated as

$$
\begin{aligned}
& \mathrm{EPS}=\beta_{0}+\beta_{1} \mathrm{SR}+\beta_{2} \mathrm{PLR}+\beta_{3} \mathrm{MPR}+\beta_{4} M L R+\beta_{5} L S R+\mu \\
& \mathrm{EBIT}=\beta_{0}+\beta_{1} \mathrm{SR}+\beta_{2} \mathrm{PLR}+\beta_{3} \mathrm{MPR}+\beta_{4} M L R+\beta_{5} L S R+\mu
\end{aligned}
$$


where

EPS $=$ earnings per share

$\mathrm{EBIT}=$ earnings before interest and tax

$\mathrm{SR}=$ short term savings rate

$\mathrm{PLR}=$ prime lending rate

$\mathrm{MPR}=\quad$ monetary policy rate

MLR $=$ maximum lending rate

$\mathrm{LSR}=$ long-term savings rate

$\beta_{0}=$ intercept term

$\beta_{1}-\beta_{4}=$ coefficients

$\mu=$ error term

A. The Statistical (First-Order) Approach: The following statistical tools are employed in our estimated data analyses:

1. R-Squared (Coefficient of Determination): The R-square otherwise known as coefficient of determination is used to measure goodness of fit. In other words, it tells us the extent to which changes in the explanatory variables can explain change in the dependent variables. It is measured in percentage.

2. The t-Test: This is a test of the permanent estimate to ascertain whether the explanatory variables are statistically significant or not. The $5 \%$ level of significance is chosen to carry out this test.

3. The F-test: This is a test of overall significance. It is used to ascertain whether the overall parameter estimate is statically significant or not. The $5 \%$ level of significance is chosen to carry out this test.

\section{Method of Data Analysis}

The data obtained in this study are estimated and analyzed following prevalent econometric procedure that include:

\section{Unit Root Test}

Most time series have unit roots as demonstrated by many studies including Nelson and Plosser (1982), Stock and Watson (1988) and Campbell and Peron (1991). Therefore, the means of variance of such time series are not independent of time. Conventional regression techniques based on non-stationary time series produce spurious regression and statistics may simply indicate only correlated trends rather than true relationship (Granger \& Newbold, 1974). 
Spurious regression can be detected in a regression model by low Durbin Watson and relatively moderate $\mathrm{R}^{2}$.

Therefore, to distinguish between correlation that arises from share trend and one associated with an underlying causal relationship, we use the Augmented Dickey Fuller (Dickey \& Fuller, 1979, 1981).

$$
X_{t}=\mu+\Theta X_{t-1}+\varepsilon_{t}
$$

The null hypotheses for the ADF Statistic test are $\mathrm{H}_{0}=$ non-stationary (unit root) and $\mathrm{H}_{0}=$ stationary respectively.

\section{Cointegration Test}

To search for possible long run relationships amongst the variables, we employ the Johansen and Juselius (1990) approach. It tests the null hypothesis of $r$ cointegrating vectors against the alternative hypothesis of $r+1$ cointegration vectors.

\section{Granger Causality}

In case we do not find any evidence for cointegration among the variables, the specification of the Granger causality will be a vector autoregression (VAR) in the first difference form. However, if we find evidence of cointegration, there is the need to augment the Granger-type causality test model with a one period lagged error term. This is a crucial step as noted by Engel and Granger (1987).

$$
Y_{t}=\alpha_{o}+\sum_{i=1}^{n} \alpha_{1}^{y} Y_{t-1} \sum_{i=1}^{n} X_{a 1} X \mu
$$

and

$$
X_{t}=\beta_{o}+\sum_{i=1}^{n}{ }_{\beta 1}^{y} Y_{t-1} \sum_{i=1}^{n} X_{\beta 1} X Y_{t}
$$

\section{Error Correction Model (ECM)}

Co-integration is a prerequisite for the error correction mechanism. Since co-integration has been established, it is pertinent to proceed to the error correction model.

$$
\begin{aligned}
& \mathrm{EPS}=\beta_{0}+\beta_{1} \mathrm{SR}+\beta_{2} \mathrm{PLR}+\beta_{3} \mathrm{MPR}+\beta_{4} M L R+\beta_{5} L S R+\mu \\
& \mathrm{EBIT}=\beta_{0}+\beta_{1} \mathrm{SR}+\beta_{2} \mathrm{PLR}+\beta_{3} \mathrm{MPR}+\beta_{4} M L R+\beta_{5} L S R+\mu
\end{aligned}
$$

ECM represents the Error Correction Model 


\section{RESULTS AND DISCUSSION}

The empirical stress tested results obtained from this study are presented and discussed below. First, the study presents the static regression result, followed by normality test, the unit root test, the cointegration test, vector error correction and the granger causality test.

Table 1: Static Regression Results

\begin{tabular}{|c|c|c|c|c|}
\hline \multicolumn{5}{|c|}{ Model I } \\
\hline Variables & Coefficient & Std. Error & t-Statistic & Prob. \\
\hline LSR & -0.101056 & 1.456217 & -0.069396 & 0.9453 \\
\hline MLR & 0.321151 & 1.218867 & 0.263483 & 0.7946 \\
\hline MPR & 0.802564 & 1.296659 & 0.618948 & 0.5423 \\
\hline PLR & 1.714861 & 0.809669 & 2.117979 & 0.0457 \\
\hline SR & -2.357929 & 1.073637 & -2.196207 & 0.0389 \\
\hline $\mathrm{C}$ & 20.22661 & 9.410862 & 2.149284 & 0.0429 \\
\hline R-squared & 0.606844 & & & \\
\hline Adjusted R-squared & 0.517490 & & & \\
\hline F-statistic & 6.791479 & & & \\
\hline Prob(F-statistic) & 0.000573 & & & \\
\hline Durbin-Watson stat & 1.558283 & & & \\
\hline \multicolumn{5}{|c|}{ Model II } \\
\hline Variables & Coefficient & Std. Error & t-Statistic & Prob. \\
\hline SR & -0.589517 & 0.250995 & -2.348714 & 0.0282 \\
\hline PLR & 0.495781 & 0.189285 & 2.619233 & 0.0157 \\
\hline MPR & 0.142796 & 0.303134 & 0.471066 & 0.6422 \\
\hline MLR & 0.323483 & 0.284947 & 1.135239 & 0.2685 \\
\hline LSR & -0.257895 & 0.340435 & -0.757546 & 0.4568 \\
\hline $\mathrm{C}$ & 6.589277 & 2.200077 & 2.995022 & 0.0067 \\
\hline R-squared & 0.745820 & & & \\
\hline Adjusted R-squared & 0.688052 & & & \\
\hline F-statistic & 12.91058 & & & \\
\hline Prob (F-statistic) & 0.000006 & & & \\
\hline Durbin-Watson stat & 0.917757 & & & \\
\hline
\end{tabular}

Source: E-View, 2018

Table 2: Diagnostic Test

\begin{tabular}{cccc}
\hline & \multicolumn{2}{c}{ Model I } & Coefficient \\
Variance & Uncentered & $\begin{array}{c}\text { Centered } \\
\text { VIF }\end{array}$ \\
Variables & 2.120567 & VIF & 10.30274 \\
LSR & 1.485637 & 76.73375 & 10.32510 \\
MLR & 1.681324 & 123.0579 & 5.489328 \\
MPR & 0.655563 & 62.12419 & 3.315118 \\
PLR & 1.152696 & 40.65321 & 4.959785 \\
SR & 88.56432 & 21.60293 & NA \\
C & & 16.00709 & \\
\hline
\end{tabular}




\begin{tabular}{cccc}
\hline & \multicolumn{2}{c}{ Model II } & \\
Coefficient & Uncentered & Centered \\
Variance & VIF & 4.959785 \\
SR & 0.062999 & 21.60293 & 3.315118 \\
PLR & 0.035829 & 40.65321 & 5.489328 \\
MPR & 0.091890 & 62.12419 & 10.32510 \\
MLR & 0.081195 & 123.0579 & 10.30274 \\
LSR & 0.115896 & 76.73375 & NA \\
C & 4.840337 & 16.00709 & \\
\hline
\end{tabular}

Source: E-View, 2018

Table 3: Unit Root Test

\begin{tabular}{|c|c|c|c|c|c|}
\hline \multicolumn{6}{|c|}{ Model I } \\
\hline \multirow[t]{2}{*}{ Variables } & \multirow[t]{2}{*}{ ADF } & \multicolumn{3}{|c|}{ Mackinnon Critical Value } & Prob \\
\hline & & $1 \%$ & $5 \%$ & \multicolumn{2}{|c|}{$10 \%$} \\
\hline EPS & -6.366177 & -3.711457 & -2.981038 & -2.629906 & 0.0000 \\
\hline LSR & -6.576355 & -3.711457 & -2.981038 & -2.629906 & 0.0000 \\
\hline MLR & -8.965451 & -3.737853 & -2.991878 & -2.635542 & 0.0000 \\
\hline MPR & -5.691206 & -3.724070 & -2.986225 & -2.632604 & 0.0001 \\
\hline PLR & -7.352689 & -3.711457 & -2.981038 & -2.629906 & 0.0000 \\
\hline SR & -7.985075 & -3.711457 & -2.981038 & -2.629906 & 0.0000 \\
\hline \multirow[t]{2}{*}{ Variables } & ADF & \multicolumn{3}{|c|}{$\begin{array}{l}\text { Model II } \\
\text { Mackinnon Critical Value }\end{array}$} & Prob \\
\hline & & $1 \%$ & $5 \%$ & & \\
\hline EBIT & -7.427906 & -3.711457 & -2.981038 & -2.629906 & 0.0000 \\
\hline LSR & -6.576355 & -3.711457 & -2.981038 & -2.629906 & 0.0000 \\
\hline MLR & -8.965451 & -3.737853 & -2.991878 & -2.635542 & 0.0000 \\
\hline MPR & -5.691206 & -3.724070 & -2.986225 & -2.632604 & 0.0001 \\
\hline PLR & -7.352689 & -3.711457 & -2.981038 & -2.629906 & 0.0000 \\
\hline SR & -7.985075 & -3.711457 & -2.981038 & -2.629906 & 0.0000 \\
\hline
\end{tabular}

Source: E-View, 2018

Table 4: Cointegration Test

\begin{tabular}{|c|c|c|c|c|}
\hline \multicolumn{5}{|c|}{ Model I } \\
\hline No. of CE(s) & Eigenvalue & Statistic & Critical Value & Prob.** \\
\hline None $*$ & 0.902262 & 145.1806 & 95.75366 & 0.0000 \\
\hline At most $1 *$ & 0.724860 & 84.71862 & 69.81889 & 0.0021 \\
\hline At most $2 *$ & 0.621338 & 51.16622 & 47.85613 & 0.0236 \\
\hline At most 3 & 0.446130 & 25.91734 & 29.79707 & 0.1312 \\
\hline At most 4 & 0.238007 & 10.55587 & 15.49471 & 0.2404 \\
\hline At most 5 & 0.125564 & 3.488592 & 3.841466 & 0.0618 \\
\hline
\end{tabular}




\begin{tabular}{|c|c|c|c|c|}
\hline \multicolumn{5}{|c|}{ Model II } \\
\hline No. of CE(s) & Eigenvalue & Statistic & Critical Value & Prob.** \\
\hline None $*$ & 0.928877 & 137.1211 & 95.75366 & 0.0000 \\
\hline At most 1 & 0.655539 & 68.39426 & 69.81889 & 0.0646 \\
\hline At most 2 & 0.517250 & 40.68409 & 47.85613 & 0.1989 \\
\hline At most 3 & 0.417627 & 21.74941 & 29.79707 & 0.3126 \\
\hline At most 4 & 0.149378 & 7.692645 & 15.49471 & 0.4988 \\
\hline At most 5 & 0.125483 & 3.486177 & 3.841466 & 0.0619 \\
\hline
\end{tabular}

Source: E-View, 2018

Table 5: Error Correction Model

\begin{tabular}{|c|c|c|c|c|}
\hline \multicolumn{5}{|c|}{ Model I } \\
\hline Variable & Coefficient & Std. Error & t-Statistic & Prob. \\
\hline $\mathrm{C}$ & 2.635414 & 1.770790 & 1.488270 & 0.1750 \\
\hline $\mathrm{D}(\mathrm{EPS}(-1))$ & 0.034094 & 0.254224 & 0.134110 & 0.8966 \\
\hline $\mathrm{D}(\operatorname{LSR}(-1))$ & -0.816559 & 1.332999 & -0.612573 & 0.5572 \\
\hline $\mathrm{D}(\operatorname{LSR}(-2))$ & -1.539232 & 1.694404 & -0.908421 & 0.3902 \\
\hline $\mathrm{D}(\operatorname{LSR}(-3))$ & -2.214132 & 1.642204 & -1.348269 & 0.2145 \\
\hline $\mathrm{D}(\operatorname{MLR}(-1))$ & -1.184353 & 0.792376 & -1.494685 & 0.1734 \\
\hline $\mathrm{D}(\operatorname{MLR}(-2))$ & -0.338711 & 0.884115 & -0.383107 & 0.7116 \\
\hline $\mathrm{D}(\operatorname{MLR}(-3))$ & 1.050185 & 1.034580 & 1.015083 & 0.3398 \\
\hline $\mathrm{D}(\mathrm{MPR}(-3))$ & -0.570064 & 1.000356 & -0.569861 & 0.5844 \\
\hline $\mathrm{D}(\operatorname{PLR}(-1))$ & 0.531870 & 1.055963 & 0.503683 & 0.6281 \\
\hline $\mathrm{D}(\operatorname{PLR}(-2))$ & 1.562341 & 0.903393 & 1.729414 & 0.1220 \\
\hline $\mathrm{D}(\operatorname{PLR}(-3))$ & 0.098367 & 0.823250 & 0.119486 & 0.9078 \\
\hline $\mathrm{D}(\mathrm{SR}(-1))$ & 1.732879 & 1.449782 & 1.195268 & 0.2662 \\
\hline $\mathrm{D}(\mathrm{SR}(-2))$ & 2.174667 & 1.436335 & 1.514038 & 0.1685 \\
\hline $\mathrm{D}(\mathrm{SR}(-3))$ & 0.757908 & 2.142561 & 0.353739 & 0.7327 \\
\hline $\operatorname{ECM}(-1)$ & -0.671191 & 0.378783 & -1.771965 & 0.1143 \\
\hline $\mathrm{R}$-squared & 0.841375 & & & \\
\hline Adjusted R-squared & 0.543952 & & & \\
\hline F-statistic & 2.828886 & & & \\
\hline $\begin{array}{l}\text { Prob(F-statistic) } \\
\text { Durbin-Watson }\end{array}$ & 0.070585 & & & \\
\hline stat & 1.507512 & & & \\
\hline \multicolumn{5}{|c|}{ Model II } \\
\hline Variable & Coefficient & Std. Error & t-Statistic & Prob. \\
\hline $\mathrm{C}$ & 0.999518 & 0.401942 & 2.486724 & 0.0322 \\
\hline $\mathrm{D}(\operatorname{EBIT}(-1))$ & 0.137267 & 0.242140 & 0.566889 & 0.5833 \\
\hline $\mathrm{D}(\operatorname{MLR}(-1))$ & -0.449090 & 0.164456 & -2.730770 & 0.0212 \\
\hline $\mathrm{D}(\operatorname{MLR}(-2))$ & 0.108525 & 0.185406 & 0.585335 & 0.5713 \\
\hline $\mathrm{D}(\operatorname{MLR}(-3))$ & 0.012355 & 0.153366 & 0.080561 & 0.9374 \\
\hline $\mathrm{D}(\operatorname{MPR}(-1))$ & 0.171335 & 0.178506 & 0.959828 & 0.3598 \\
\hline $\mathrm{D}(\mathrm{MPR}(-2))$ & -0.131478 & 0.214825 & -0.612022 & 0.5542 \\
\hline $\mathrm{D}(\mathrm{MPR}(-3))$ & -0.105496 & 0.183474 & -0.574995 & 0.5780 \\
\hline
\end{tabular}


African Journal of Accounting and Financial Research

ISSN: $2682-6690$

Volume 4, Issue 3, 2021 (pp. 194-214)

www.abjournals.org

\begin{tabular}{crrrr}
\hline D(SR(-2)) & 0.654043 & 0.267711 & 2.443090 & 0.0347 \\
D(SR(-3)) & 0.345412 & 0.243530 & 1.418356 & 0.1865 \\
D(LSR(-1)) & 0.161792 & 0.177524 & 0.911380 & 0.3835 \\
D(LSR(-2)) & -0.456608 & 0.261816 & -1.743999 & 0.1118 \\
D(LSR(-3)) & -0.155829 & 0.236042 & -0.660175 & 0.5241 \\
ECM(-1) & -0.731583 & 0.244032 & -2.997895 & 0.0134 \\
R-squared & 0.741399 & & & \\
Adjusted R-squared & 0.405218 & & & \\
F-statistic & 2.828886 & & & \\
F-statistic & 2.205355 & & & \\
Prob(F-statistic) & 0.107837 & & & \\
DW & 1.833106 & & & \\
\hline
\end{tabular}

Source: E-View, 2018

Table 6: Test of Causality

\begin{tabular}{lccc}
\hline Null Hypothesis: & Obs & F-Statistic & Prob. \\
\hline LSR does not Granger Cause EPS & 26 & 0.14258 & 0.8679 \\
EPS does not Granger Cause LSR & & 0.46809 & 0.6326 \\
MLR does not Granger Cause EPS & 26 & 0.01362 & 0.9865 \\
EPS does not Granger Cause MLR & & 0.06129 & 0.9407 \\
MPR does not Granger Cause EPS & 26 & 0.26203 & 0.7720 \\
EPS does not Granger Cause MPR & & 0.66904 & 0.5228 \\
PLR does not Granger Cause EPS & \multirow{2}{*}{26} & 0.13772 & 0.8721 \\
EPS does not Granger Cause PLR & & 3.98017 & 0.0342 \\
SR does not Granger Cause EPS & 26 & 0.57757 & 0.5699 \\
EPS does not Granger Cause SR & & 2.20028 & 0.1357 \\
\hline
\end{tabular}

Source: E-View, 2018

\section{DISCUSSION OF RESULTS}

Table I presents the static regression results. The results showed in the model that the independent variables can predict variation in the dependent variable by 60.8 percent while the remaining 39.2 percent can be explained by variables not captured in the model. The coefficient of frequency statistics and probability validate the use of the model and variables. The Durbin Watson statistics proved the presence of serial autocorrelation among the variables. The results further found that long-term and short-term interest rates have a negative relationship with earnings per share of the commercial banks while maximum lending rate, prime lending rate and monetary policy rate have a negative relationship with the dependent variable. Model II found that the explanatory variables can explain 68.8 percent variation on the dependent variable while the remaining 31.2 percent can be explained by variables not included in the model. The f-statistics proved that the model is significant while the beta coefficient of the variables proved that short-term savings rate and long-term savings rate have a negative relationship with earnings before interest rate and tax while maximum lending rate, prime lending rate and monetary policy rate have a negative relationship with the dependent variable. 
Table II presents the collinearity test of the variables. The results found tolerance values are less than 1.00 but above 0.1 in all the variables examined in the model with relation to commercial banks soundness. This is inverse to the traditional level and the rule of thumb which is contrary to testing the multicollinearity on the tolerance. The above table illustrates the collinearity diagnostic test result. The result shows an Eigen value that corresponds to the highest conditional index and the variance constant is less than 0.05 at $5 \%$ level of significance. This indicates a significant relationship between the dependent and the independent variables in the long run for the two models.

The augmented Dickey Fuller unit root test in Table III found that all the variables are stationary at first difference and integrated in the order of I(1); we therefore accept the alternate hypothesis.

We tested the long run relation of the variables using the Johansen cointegration test. The results in Table IV found that model one had at least two cointegrating equations while model two found at least one cointegrating equation. We conclude that there is a long run relationship between the dependent variables and the independent variables.

We presented the error correction model results in Table V. Model one proved adjusted speed of 67 percent while model two proved adjusted speed of 74 percent. The results further proved the effect of the independent variables on the dependent variables at various lags. The causality test presented in Table VI found no causal relationship among the variables except unidirectional relationship from earnings per share to prime lending rate.

\section{CONCLUSION AND RECOMMENDATIONS}

The general objective of the study was to give an analysis of the interest rate channel of monetary transmission mechanism and commercial banks earnings in Nigeria. The findings suggest 60 and 68 percent variation in earnings per share, and earnings before interest and tax can be explained by variation in the interest channel of the monetary policy transmission mechanism. The findings of this study are in line with the findings of Khan and Sattar (2014) that there is a positive and significant relationship between interest rate and profitability. Baghan and Chowdy (2010) found that bank profit is derived from the difference between the interest rate it charges by lending and the interest rate it offers depositors. Okoye and Eze (2013) found that lending rate and monetary policy rate have significant and positive effects on the performance of Nigerian DMBs, and Enyioko (2012) found that interest rate policies have not improved the overall performances of banks significantly.

\section{Recommendations}

There is a need for constant revision of policy and instruments targeting framework and operating procedure to enhance monetary policy effectiveness, particularly in stabilizing the interest rate. There is a need for the Central Bank of Nigeria to harmonize and combine the functionality of all channels to achieve optimum earnings goals of monetary transmission mechanism. This could be complemented with the adoption of one policy rate used to signal the market and by doing so will reduce duplication of activities by different rates and lead to optimum outcomes of monetary policy goals. It is also advisable that the Central Bank of 
Nigeria combines other transmission channels of monetary policy to achieve increased earnings of commercial banks in Nigeria.

\section{REFERENCES}

Adam, C., Maturu, B., Njuguna, N., \& O’Connell, S. (2010). Building a Kenyan monetary regime for the 21st Century.Central Bank of Kenya Research paper 15.

Andrle, M., Berg, A., \& Morales, R. A. (2013).Forecasting and monetary policy analysis in low income countries.Food and non-Food Inflation in Kenya.IM F Working Paper WP 13/16, 13-28.

Berg, A., Charry, L., Portillo, R., \&Vlcek, J. (2013).The monetary transmission mechanism in the Tropics.A Narrative Approach.IMF Working Paper WP/13/197. 13-45

Bonga -Bonga, L. (2010). Monetary policy and long term interest Rate in South Africa. International Business and Economics Research Journal, 43-54.

Campbell, J., Shiller, R., (1991). Yield spreads and interest rates. The rate movements: A Bird's Eye View. Review of Economic Studies, 5(8), 495-514.

Cheng, K. c. (2006). A VAR analysis of Kenya's monetary policy transmission mechanism: How does the Central Bank Repo rate affect the economy?.IMF Working Paper WP06/300. 12-24

Cheong, D., \&Boodoo, E. (2008). The monetary transmission mechanism: a closer look at the interest rate channel in Trinidad and Tobago. Research and Policy Department, Central Bank of Trinidad and Tobago.

Culbertson J.M. (1959). The term structure of interest rates.Quarterly Journal of Economics, 7(1), 485-517,

Davoodi, H. R., Dixit, S., \& Pinter, G. (2013). Monetary transmission mechanism in East African community: An Empirical Investigation. IMF Working Paper.WP 13/39.

Deger, A., \&Adem, A., (2011). Bank specific and macroeconomic determinants of commercial bank Profitability: Empirical evidence from Turkey. Business and Economics Research Journal. 2,(2), 139-152

Demirguc-Kunt, A. \& Huizinga, H. (1999).Determinants of Commercial Bank Interest Margins.Arabian Journal of Business and Management Review (OMAN Chapter) 3, (11).

Drobyshevsky O.,(1999). sovremennoyteoritvremennoystrukturyprocentnyhstavok. Osnovnyegipotezy i modely. M.: IET, WP 14P.

Engle, R. F., \& Granger, C. J. (1987).Cointegration and error-correction representation, estimation and testing.Econometrica, 55, 251-278.

Enyioko, N., (2012). Impact of interest rate policy and performance of deposit money banks in Nigerian.Global Journal of Management and Business Research. 12 (21) 224-258.

Eregha, P.B., (2010). Interest rate variation and investment determination in Nigeria.International Business Management. 4(2), 41-46

Evans, C.L., Marshall, D.A., (2001). Economic determinants of the term structure of nominal interest rates. Working paper, Federal Reserve Bank of Chicago, Chicago, IL

Gadise, G., (2014). Determinants of Non-Performing Loans: Empirical Study in Case of Commercial Banks in Ethiopia. A Thesis submitted to the school of Post Graduate in Partial Fulfillment of the Requirements for the Degree of Masters of Science (M.Sc) in Accounting and Finance Jimmy University. 
Granger, C.W.J, (1969). Investigating causal relations by econometric models and cross research spectral Methods. Econometrica, 3(7), 428-438.

Gujarati, N. D, \& Porter, C.D.(2009). Basic Econometrics (5thEd).McGraw.Hill

Gul, S., Faiza, I., \& Khalid, Z., (2011). Factors affecting bank Profitability in Pakistan. The Romanian Economic Journal. 2(3) 6-9

James, M., \&Tamim, B. (2001). A peek inside the black box: the monetary transmission mechanism in Japan. International Monetary Fund 48(1), 40-49.

Jean, B., Giannoni, P. M., \& Benoit, M. (2008). How has the euro changed the monetary transmission mechanism? The National Buraeu of Economic Research, 116 -118.

Johannes, P. (2013). Interest rate passes through in Namibia. Journal of Emerging Issues in Economics Finance and Banking

Khan, F., Anuar, M. A., Choo, L. G., \& Khan, H., (2011). Determinants of bank Profitability in Pakistan: A Case Study of Pakistani Banking Sector. World Applied Sciences Journal, 15(10), 1484-1493.

Khrawish, H.A., (2011). Determinants of Commercial Banks Performance: Evidence from Jordan. International Research Journal of Finance and Economics, 81.

Konfi, S., (2012).Determining causes and impact of nonperforming loans on the operations of microfinance institutions: A Case of Sinapi Aba Trust in Ghana. Published thesis (MBA), Kwame Nkrumah University

Mehra, Y.P., (1996). Monetary policy and long-term interest rates. Federal Reserve Bank of Richmond Economic Review, 82(3) 27-49

Mikalai, T., (2006).Term structure of interest rates analyses.The Case of Belarus. A Thesis Submitted in Partial Fulfillment of the Requirements for the Degree of Master of Arts in Economics. National University of Kyir-Mohyla.

Misati, N. R., Njoroge, L., Kamau, A., \&Ouma, s. (2010). Financial innovation and monetary policy transmission in Kenya.International Research Journal of Finance and Economics.

Mishkin, F. S. (1995). Symposium on the monetary transmission mechanism.Journal of Economic Perspectives, 3-10

Mishra, P., \&Montiel, P. (2012). How Effective is Monetary Transmission in Income Countries? A survey of Empirical Evidence.IMF Working paper WP, 5-25.

Molyneux, P., \&Thorton, J., (1992). .Determinants of European bank profitability: A note J. Bank. Finance, 16 (6)1173-1178.

Morales, A. R., \&Raei, F. (2013).Evolving role of interest rate and exchange rate channel in monetary transmission in EAC countries.IMF Working Paper WP/13/X.

Murthy, Y., Sree, R., (2003). A Study on Financial Ratios of major Commercial Banks.Research Studies, College of Banking \& Financial Studies, Sultanate of Oman

Ngerebo-a, T.A., \& Lucky, A. L., (2016). Interest Rates and Deposit Money Bank's Profitability: Evidence from Nigeria (1980 - 2014). International Journal of Empirical Finance, 5 (1), $22-35$.

Ogunbiyi,S. S., \&Ihejirika, P.,(2014). Interest Rates and Deposit Money Banks' Profitability Nexus: The Nigerian Experience. Arabian Journal of Business and Management Review (OMAN Chapter). 3(11)133-148.

Okoye, V ., \&Eze, O. R., (2013). Effect of bank lending rate on the performance of nigerian deposit money banks. International Journal of Business and Management Review 1. (1),34-43. 
Omiete, V.O., \&Onyemachi, M. O., (2015). Money Supply and Asset Prices in Nigeria (2008-2013). An empirical Review.Research Journal of finance and Accounting. 6(10) 45-56.

Ransford, Q.C., Collins, O.K, Owusu, A., (2014). The Determinants of Bank Interest Rates Spread in Ghana.International Journal of Economics Behaviour and Organization. 2 (4) 49-57.

Riaz, S., \&Mehar, A., (2013).The impact of bank specific and macroeconomic indicators on the profitability of commercial banks.Journal 16(47 Romanian Economic), 91-110

Saborowski, C., \& Weber, S. (2013). Assessing the determinants of Interest Rate Transmission Through Conditional Impulse Response Function. IMF Working Paper.WP/13/23.

Stelios, K., Yannis, P., \&Prodomos, V. (2010). Interest rate pass through in the euro-zone and the usa: implication for monetary policy in context of recent financial crises. Centre for Panning and Economic Research (KEPE), 10-15.

Taylor, J. (1995). The monetary transmission mechanism: an empirical framework. Journal of Economic Perspectives, 11-26. 